\title{
Transformasi Peran Fatayat NU dalam Membangun Daerah Jambi
}

\section{Transformation of NU Fatayat Role in Building Jambi Region}

\author{
Halimah Dja'far \\ Fakultas Adab UIN Sulthan Thaha Saifuddin Jambi \\ Jl. Jambi-Muaro Bulian Km. 16 Simpang Sungai Duren Muaro Jambi, Jambi.
}

\begin{abstract}
Abstrak: Tulisan ini membicarakan tentang Fatayat Nahdatul Ulama (NU) di kota Jambi, dalam artikel ini penulis memfokuskan pada transformasi peran Fatayat NU Cabang Jambi dalam meningkatkan kualitas pendidikan masyarakat, meskipun Fatayat Cabang Jambi sudah eksis ditengah masyarakat dan telah mejalankan programnya bergerak dibidang sosial, agama, peran perempuan, akan tetapi hal ini baru dilakukan sebagai mitra kerja pemerintah, semestinya jika organisasi masyarakat ini dikelola dengan baik, memungkinkan Fatayat NU dapat menjadi aktor intelektual dalam meningkatkan kualitas pendidikan di kota Jambi.
\end{abstract}

\begin{abstract}
This article discusses the Nahdatul Ulama (NU) Fatayat in Jambi, in this article the author focuses on the transformation of the role of NU Fatayat Jambi Branch in improving the quality of public education, even though Fatayat Jambi Branch already exist in the community and has run its program in social, the role of women, but this is only done as a partner of the government, should if this community organization is well managed, allowing Fatayat NU can become an intellectual actor in improving the quality of education in the city of Jambi.
\end{abstract}

\section{A. Pendahuluan}

Berbagai alasan yang dikemukan atas kemunculan organisasi perempuan, diantaranya untuk melawan penindasan dan kesemena-menaan terhadap hak azasi manusia, untuk meningkatkan keharmonisan antar sesama bahkan ada yang beralasan hadirnya sebuah organisasi perempuan untuk memastikan bisa mempertahankan hidup dalam krisis ekonomi keluarga, 


\section{HALIMAH DJA'FAR}

dan pada akhirnya organisasi perempuan mengarahkan perempuan untuk memainkan peran dalam perkembangan kebijakan dalam membangun negeri.

Semangat organisasi perempuan Islam tidak kalah pentingnya dalam menunjukkan kiprahnya untuk ikut serta dalam membangun negeri ini, diantara organisasi perempuan Islam ada yang bersifat independen dan ada pula yang berada di bawah naungan partai tertentu, khusus nya di daerah Jambi terdapat misalnya Al-Hidayah, BKMT, Wanita Islam, Muslimat, Aisyiah, Salimah, Fatayat NU, IPPNU, Nasyiatul Asyiyah, Persistri, Wanita SarikatSarikat Islam dan banyak lagi yang lainnya.

Setiap organisasi perempuan Islam memiliki ideologinya masingmasing, Kunto Wijoyo mencatat terdapat empat perkembangan ideologi lembaga perempuan, terutama yang berada dibawah naungan organisasi Islam. 1) penegasan kedudukan wanita ditengah dunia laki-laki, 2) penegasan pergerakan dan hak-hak wanita, 3) penegasan wanita sebagai pembina rumah tangga, 4) penegasan peran wanita dalam pembangunan. Tampaknya keberadaan organisasi perempuan Islam yang telah lahir belum maksimal dalam menyelesaikan secara konkrit masalah-masalah terkait dengan pembangunan mental spiritual, diskriminasi dan kekerasan perempuan. Selain itu, sasaran program masing-masing organisasi perempuan Islam masih ditujukan untuk kalangan dan golongan sendiri, belum banyak dinikmati oleh masyarakat luas ${ }^{1}$.

Fatayat NU merupakan salah satu organisasi perempuan Islam diantara sekian banyak organisasi perempuan yang berada di kota Jambi yang telah disebutkan di atas. Organisasi masyarakat yang sudah berkembang ini baru memperlihatkan kegiatan mereka lebih kepada pembinaan anggota dan menghidupkan pengajian serta sedikit berpartisipasi dalam bidang sosial. Padahal jika organisasi perempuan Islam tersebut dikelola dengan serius banyak peluang yang memungkinkan organisasi 
perempuan Islam ini dapat berperan serta dalam membangun masyarakat kota Jambi.

Fatayat NU adalah salah satu organisasi wanita Islam yang berada di bawah organisasi Nahdatul Ulama, selain itu terdapat pula Muslimat, Anshor, IPNU, IPPNU, meskipun Fatayat NU berada di bawah naungan NU, namun organisasi ini mempunyai badan otonom dan diberi keleluasaan dalam mengatur rumah tangganya sendiri, dan mempunyai AD, ART sendiri serta mempunyai VISI dan MISI sendiri².

Keberadaan Fatayat NU (PC) kota Jambi selama ini berpartisipasi dalam bidang sosial ekonomi dan pembinaan keagamaan dan berperan serta dalam menangkal pemahaman radikalisme sebagai mitra pemerintah, namun kegiatan ini baru terbatas pada pembinaan internal, Sebagaimana yang diungkapkan oleh Fatimah Abbas selaku Wakil ketua Organisasi Fatayat NU Propinsi, banyak kegiatan yang sudah dilakukan dalam rangka ikut berperan serta dalam pembangun daerah Jambi, dalam hal ini bekerja sama dengan pemerintah daerah serta mengikuti kegiatan yang ada dipusat. Seperti workshop dan lain-lain. ${ }^{3}$

Perlu diketahui bahwa Fatayat NU Kota kedepan, akan mengadakan trnasformasi dibidang pendidikan, Sebagaimana yang diutarakan oleh Nurhayati selaku ketua Pengurus Cabang (PC) fatayat NU Kota. Kedepan dalam rencana akan segera membuka program pendidikan, seperti sekolah Ibtidaiyayah MTS, MAN, karena sebelumnya beliau sudah membuka sekolah LPTQ di Kabupaten Tanjab Timur. Berdasarkan pengalaman di Tanjab Timurlah, maka kedepan dia ingin mengadakan tranasformasi dibidang pendidika.4 Disamping itu untuk meningkatkan peran Fatayat NU, maka oraganisai Fatayat NU Mengadakan beberapa kegian diantaranya 1 . Mengadakan workshop untuk peningkatan sumber daya perempuan, karena hal ini sangat penting bagi perempuan sebagai ibu dan sebagai pendidik (madrasah) bagi anak-anaknya. 2. Mengadakan kegiatan sosialisasi tentang 
bahaya faham radikalisme Islam, pelaksanaan program ini bekerjasama dengan pemerintah daerah Kota Jambi. ${ }^{5}$

Berdasarkan paparan diatas, Penulis bermaksud mengungkapkan lebih jauh tentang profil dan bagaimana peran organisasi Fatayat NU serta bagaimana transformasi peran Fatayat NU (PC) Jambi dalam meningkatkan kualitas pendidikan bagi masyarakat kota Jambi.

\section{B. Fatayat NU, Pembangunan, dan Pendidikan}

\section{Fatayat NU}

Fatayat NU adalah oraganisasi perempuan Islam, merupakan badan otonom di bawah organisasi Nahdatul Ulama (NU) bersifat sosial keagamaan, kemasyarakatan dan kekeluargaan. Organisasi ini beraqidah Ahlussunnah wal-Jama'ah.

Pembentukan Fatayat NU berdasarkan SK PBNU No. 574/U/Feb/1950 dikeluarkan dan dideklarasikan pada tanggal 14 Februari 1950 di Jakarta, atas desakan perempuan-perempuan NU dalam Muktamar NU ke-18 pada tanggal 20 April-3 Mei 1950 di Jakarta, terpilh sebagai ketua I adalah Nihayah Bakri berasal dari Surabaya dan Aminah Mansur sebagai ketua II berasal dari Sidoarjo. Pada masa ini hanya mempunyai dua bagian yaitu bagian penerangan dan pendidikan. ${ }^{6}$

Fatayat NU berdiri dengan tujuan untuk (1) membentuk pemudi atau wanita muda Islam yang bertaqwa kepada Allah SWT, berbudi luhur, beramal, cakap dan bertanggung jawab, serta berguna bagi agama, nusa, dan bangsa; (2) mewujudkan rasa kesetiaan terhadap asa, akidah dan tujuan Nahdatul Ulama dalam menegakkan syariat Islam; dan (3) mewujudkan masyarakat adil dan makmur yang merata serta diridai Allah SWT7.Untuk mewujudkan tujuan tersebut, Organisasi yang berlambang setangkai bunga melati ini berusaha menghimpun dan membina pemudi Islam dan meningkatkan mutu pendidikan, pengajaran, keterampilan, dan 
memperluas ilmu pengetahuan yang berguna bagi agama, nusa dan bangsa.

Keanggotaan Fatayat NU terdiri dari perempuam muda Islam yang memiliki komitmen dan tidak berafiliasi dengan organisasi yang tidak satu Visi dengan Fatayat NU berumur 20 sampai 45 tahun melalui rekrutmen Anak Ranting dengan mengisi formulir. keanggotaan tersebut, terdiri dari anggota biasa dan anggota kehormatan, syarat menjadi anggota sebagaimana yang tertuang di dalam Peraturan Rumah Tangga Fatayat(PRT) pasal 5 tentang Hak keanggotaan diantaranya adalah menghadiri kegiatan yang diadakan oleh organisasi, anggota tidak diperkenankan merangkap menjadi anggota organisasi lain yang tidak satu Visi dengantujuan NU. ${ }^{8}$

Di Jambi, Fatayat NU sudah terbentuk sejak tahun 1956 di bawah kepemimpinan Dahniar Wahab Nasution, pada masa ini kepengurusan hanya terdapat dua bagian yaitu bagian penerangan dan bagian pendidikan. Setelah pergantian pengurus, selanjutnya ketua terpilih adalah Jawanis dan dilanjutkan oleh Fadlilah Husin hingga sekarang. Untuk kepengurusan di kota Jambi ketua pertama yang terpilih adalah Fitri HB dan kemudian dilanjutkan oleh ketua berikutnya adalah Nurjanah hingga sekarang.

Khittah perjuangan Fatayat kota Jambi tidak terlepas dari dinamika politik dan budaya yang berkembang, serta sumber daya manusia pimpinan dan pengurus dalam sebuah organisasi tersebut, karena sumber daya manusia merupakan elemen utama dalam sebuah organisasi jika dibandingkan dengan elemen-elemen lainnya misalnya tekhnologi, keuangan dan informasi. Manusia merupakan elemen yang berperan aktif dalam mengendalikan semua sumber daya yang ada dalam organisasi. ${ }^{9}$

Dari data yang dihimpun di lapangan kepengurusan Fatayat Wilayah propinsi (PW) dan Pengurus Cabang (PC) kota jambi menunjukkan sudah memiliki sumber daya manusia yang sangat 
memadai, hal ini terlihat dari pendidikan terakhir yang dimiliki pengurus dapat dikatakan berbanding 98\% starata satu(S1) dan hanya 2\% yang berpendidikan SLTA. ${ }^{10}$

Selain dari sumber daya manusia yang memadai, budaya organisasi juga sangat menentukan keberhasilan dan tercapainya tujuan sebuah organisasi, karena organisasi adalah kumpulan beragam individu dengan berbagai latar belakang yang berbeda yang dapat bersinergi dan dimanfaatkan demi kemajuan organisasi.

Kultur organisasi adalah cara berfikir dan melakukan sesuatu yang mentradisi, yang dianut bersama oleh semua anggota organisasi dan para anggota baru harus mempelajari atau paling tidak menerimanya sebagian agar mereka diterima sebagai bagian organisasi. ${ }^{11}$

Tradisi ormas Fatayat NU Cabang (PC) kota Jambi yang berkembang adalah mengadakan silaturrahmi setiap satu bulan sekali pertemuan diadakan di rumah ketua pengurus yang merupakan sekretariat Fatayat NU Pengurus Cabang (PC) Jambi, dengan agenda membicarakan kegiatan-kegiatan yang akan dilaksanakan bersama. ${ }^{12}$ Pertemuan ini kadang juga melibatkan anggota Fatayat yang berkontribusi dalam setiap kegiatan yang dilaksanakan.

Salah satu program keja Fatayat NU (PC) Jambi yang sudah dilaksanakan adalah Latihan Kepemimpinan Dasar(LKD) dan Latihan Kepemimpinan Lanjutan(LKL), kegiatan ini bertujuan untuk memberi bekal kepada anggota maupun pengurus tentang manajemen kepemimpinan, kegiatan ini merupakan gabungan pragram kerja pengurus propinsi dan kota, belum ada pembinaan secara rutin dan berkala bagi pengurus dan anggota. ${ }^{13}$

Selain itu, Pengurus Cabang(PC)telah melaksanakan Seminar nasional dengan tema"Penguatan Peran Perempuan dalam Mengatasi Faham Radikalisme" yang melibatkan peserta dari berbagai perwakilan organisasi perempuan yang berada di kota Jambi, kegiatan ini bertujuan 
untuk mensosialisasikan bahaya paham radikalisme bagi keberlangsungan kehidupan berbangsa dan bernegara. ${ }^{14}$

\section{Keanggotaan}

Anggota ormas Fatayat NU kota Jambi adalah perempuan-perempuan muda Islam yang berumur minimal 20 tahun sampai maksimal berumur 45 tahun. ${ }^{15}$ Rekrutmen anggota melalui Pimpinan Anak Ranting dengan cara mengisi pormulir yang diajukan kepada Pimpinan Anak Ranting. Utuk daerah Jambi dilakukan melaui organisasi kampus dengan melibatkan Organisasi Mahasiswa Persatuan Mahasiswa Islam Indonesia(PMII) ini disebut dengan anggota biasa. ${ }^{16}$ Meskipun demikian anggota Fatayat NU(PC) Jambi sampai hari ini belum mempunyai Data Base karena untuk mendata anggota membutuhkan waktu yang lama.

Selain anggota biasa terdapat pula anggota Kehormatan yang diminta oleh Pimpinan Fatayat NU di tingkatan masing-masing sesuai kebutuhan. Pengajuan atau penunjukan menjadi anggota kehormatan harus memenuhi aturan yang sudah ditetapkan pasal 2 ayat (2) serta memberi tembusan kepada pimpinan tingkat atas. ${ }^{17}$ Untuk kota Jambi belum ada anggota kehormatan yang terdaftar secara administrasi.

\section{Pembangunan}

Istilah pembangunan dalam pandangan Ali M.A. Rahman, menunjukkan makna subjektif dan merujuk kepada sesuatu proses. ${ }^{18}$ Yang dimaksud adalah proses dari satu tahap ke tahap lain, suatu proses perkembangan dan usaha untuk memajukan serta menyajahterakan kehidupan masyarakat. Dalam kata pembangunan terdapat dua kata yang berlawanan, yaitu merujuk kepada "yang terbelakang" atau "mundur" dan satu lagi merujuk kepada "maju". ${ }^{19}$ Dapat dikatakan bahwa pembangunan adalah "suatu proses transformasi, suatu perubahan masyarakat segala aspek". 20

Pembangunan adalah seperangkat usaha manusia untuk mengadakan perubahan social dan kebudayaan sesuai dengan social dari kehidupan 
berbangsa dan bernegara yang mencapai pertumbuhan peradabankehidupan social dan kebudayaan atas dasar target-terget yang telah ditetapkan. Pete L Berger menemukakan argumennya bahwa pada dsarnya pembangunan adalah persoalan yang dihadapi oleh umat mansia sekarang ini. Suatu realitas yang senjatanya ada tidak ada kehidupan suatu bangsa yang samasekali tidak menghadapi persoaln apapun, misalnya persoalan yang dihadapi oleh negara-negara yang sedang berkembang, seperti masalah kelaparan, penyakit, tingginya angka kematian kebodohan, keterbelakangan kebutuhan tempat tinggal, dan minimnya jumlah ketersediaan lapangan pekerjaan. Dengan demikian pembangunan adalah persoalan bagi para pembuat kebijakan umum yang dalam kapasitas ini adalah pemerintah. ${ }^{21}$.

Adapun tujuan dari pembangunan adalah proyeksi terjauh dari harapan-harapan dan ide-ide manusia, komponen-komponen dari yang mungkin atau masyarakat ideal terbaik yang dapat dibayangkan. ${ }^{22}$

Ada tiga elemen pembangunan yang menjadi fokus artikel ini, yaitu 1) meningkatkan kualitas kehidupan sosial, 2) aspek elemen sosial dan 3) meningkatkan penyertaan komunitas dalam pendidikan. Dalam meningkatkan kualitas kehidupan sosial, terdapat beberapa komponen penting yang perlu dicapai di dalam pembangunan kualitas kehidupan sosial, yaitu kesehatan, pangan,pendidikan, perumahan kerohanian(agama), lapangan pekerjaan, dan fasilitas umum lainnya.

Program pembangunan di kota Jambi memang sudah berlangsung sejak kota ini dilahirkan, pembangunan di berbagai bidang sosial, ekonomi, pendidikan, dan lain sebagainya tidak luput dari perhatian pemerintah kota, akan tetapi persoalan-persoalan yang muncul menyertai proses pembangunan tersebut dalam usaha meningkatkan kualitas hidup masyarakat, termasuk pascareformasi sampai pada era globalisasi saat ini persoalan yang muncul semakin komplek. Walaupun berbagai cara dan usaha yang dilakukan untuk mengatasi problem-problem tersebut, ternyata belum menunjukkan hasil yang maksimal. 
Untuk mengatasi persoalan-persoalan yang terjadi ditengah masyarakat, pemerintah dapat bekerja sama dengan pihak tertentu diantaranya dengan ormas-ormas yang berkonsentrasi dengan programprogram kemasyarakatan seperti Fatayat NU yang mempunyai komunitas terbanyak di negeri ini.

Program kerja Fatayat NU Pengurus Cabang(PC) Jambi menjadi acuan bagi kegiatan-kegiatan organisasi ini untuk meningkatkan peran serta dalam memajukan masyarakat utamanya dalam bedang sosial dan pendidikan. Adapun proses penyusunan nya dimulai dari saat rakernas yang diadakan satu kali dalam lima tahun kemudian berdasarkan hasil rakernas disusun program kerja Wilayah dan cabang.

Salah satu program kerja Fatayat NU (PC) Jambi adalah Pengkaderan dan Pendidikan. Namun, kegiatan-kegiatan yang dilaksanakan oleh pengurus cabang belum banyak bersentuhan dengan program pendidikan kalaupun ada hanya terbatas bagi internal pengurus dan anggota saja, dan kegiatan ini belum berjalan secara rutinitas.

\section{Pendidikan}

Untuk mencapai suatu tujuan, manusia memerlukan pendidikan karena berawal dari pendidikan manusia dapat menjalani kehidupannya dengan baik dan sempurna, istilah lain adalah pendidikan dapat mempengaruhi cara pandang dan cara bertindak seseorang baik pendidikan secara formal maupun pendidikan non formal. Semua orang tentu sudah tahu apa pendidikan itu, pendidikan menurut orang awam bisa saja memasukkan anak ke sekolah, mengajar mengaji, membiasakan anak berbuat kebaikan dan membiasakan bersopan santun terhadap sesama. Namun apakah pendidikan itu menurut pendapat para ahli? Marimba ${ }^{23}$ menyatakan bahwa pendidikan adalah bimbingan atau pimpinan secara sadar oleh pendidik terhadap perkembangan jasmani dan rohani anak didik menuju terbentuknya kepribadian yang utama. 
Pendidikan dalam arti lain dikemukakan Ahmad Tafsir, pendidikan ialah pengembangan pribadi dalam semua aspeknya, dengan penjelasan yang dimaksud dengan pengembangan pribadi ialah yang mencakup pendidikan oleh diri sendiri, pendidikan oleh lingkungan, dan pendidikan oleh orang lain(guru). Seluruh aspek mencakup jasmani,akal,dan hati. ${ }^{24}$ Oleh karena itu pendidikan dapat dikatakan, berbagai usaha yang dilakukan oleh guru atau pendidik terhadap seseorang(murid) agar tercapai perkembangan yang positif. ${ }^{25}$ Jadi pendidikan bukan hanya tugas seorang guru disekolah akan tetapi pendidikan dapat pula diartikan kegiatan yang berlangsung dalam sebuah komunitas yang dapat mempengaruhi sesorang baik secara fisik maupun mental dan dapat terjadi dimana saja dan kapan saja.

Usaha untuk meningkatkan pendidikan untuk masyarakat Jambi yang dilakukan oleh pemerintah kota, melalui pendidikan formal maupun pendidikan non formal semestinya dapat bekerjasama dengan ormas-ormas yang bergerak dalam berbagai aspek, bukan hanya terfokus pada sebuah organisasi tertentu yang secara politik dapat dipengaruhi untuk mendukung sekelompok orang.

\section{Peran serta Fatayat NU dalam bidang pendidikan}

\section{Problem Pendidikan di Kota Jambi}

Pendidikan di kota Jambi masih sangat ketinggalan jika dibandingkan dengan daerah lain baik di Sumatera maupun di tingkat Nasional, begitu pula halnya dengan pendidikan agama ini terjadi disebabkan belum ada anggaran yang dialokasikan untuk peningkatan mutu pendidikan oleh pemerintah Kota. ${ }^{26}$

Akibat dari kurang adanya program strategis dalam penguatan pendidikan baik pendidikan formal maupun pendidikan non formal berimbas pada banyaknya penyalah gunaan narkotika, pelacuran dan miras yang sangat tinggi ${ }^{27}$ gubernur Zumi Zola mengatakan kurang lebih ada 47 ribu pengguna narkoba di Provinsi Jambi. Angka tersebut tersebar hampir merata di 11 kabupaten dan kota28. 
Data tersebut diatas diperkuat dengan kehadiran Menteri Sosial Khofifah Indar Parawansa dalam rangka meresmikan Institusi Penerima Wajib Lapor (IPWL) Al Jannah di Desa Sungai Buluh, Kecamatan Muara Bulian, Kabupaten Batang Hari sebagai wujud negara hadir melindungi warganya ${ }^{29}$. Mensos mengharapkan setelah upaya rehabilitasi penyalahgunaan narkotika harus ada grup dukungan keluarga(famili support group) karena setelah keluar dari rehabilitasi dukungan keluarga penting untuk menguatkan korban.

Tidak ada program terdepan dalam penguatan pendidikan agama yang menjadi kiblat bila dibandingkan dengan daerah lain ${ }^{30}$ pemerintah daerah harus mampu menjadi Suporter bagi penguatan pendidikan bagi masyarakat melalui program strategis secara formal ataupun non formal, karena pendidikan merupakan salah satu instrumen dalam membangun sumber daya manusia.

Pindidikan merupakan salah satu program strategis Fatayat NU yang termaktub di dalam Program Kerja pada poin pertama, yaitu Bidang Pengembangan Organisasi, Pendidikan dan Pengkaderan ${ }^{31}$ salah satu agenda yang akan diusung oleh Fatayat NU kota Jambi adalah akan mengadakan/mendirikan pendidikan formal mulai dari tingkat Ibtidaiyah sampai ke tingkat Tsyanawiyah ${ }^{32}$.

Selain itu Program yang direncanakan meningkatkan kualitas perempuan, melakukan pendidikan dan pelatihan pada semua tingkatan yang bertujuan menjadikan perempuan sebagai kader pemimpin yang tangguh dan mampu menginplentasikan Aswaja yang rahmatan lil alamin serta memperjuangkan hak-hak perempuan ${ }^{33}$.

Usaha untuk menginplementasikan program kerja bagi Pengurus Cabang tentu saja merupakan usaha yang mudah karena NU merupakan ormas Islam di Indonesia yang mempunyai kuantitas (jumlah pengikutnya) yang besar. Hal ini dapat dilihat dari pengikutnya. Ada sejumlah $56 \%$ dari penduduk beragama Islam di Indonesia, atau sejumlah 88,7 \% dari total penduduk Indonesia, atau sejumlah 237,7 juta orang 34 . 
Program kerja pemberdayaan yang telah dilaksanakan Fatayat NU PC Jambi mencakup tiga bidang yaitu (1) bidang pengkaderan, meliputi pelatihan kemandirian dan kepemimpinan, (2) bidang kesehatan, meliputi workshop tentang kesehatan reproduksi perempuan dan pencegahan HIV/AIDS, dan (3) bidang dakwah, meliputi pengajian dan diskusi seperti cara mengatasi kekerasan dalam rumah tangga. Dalam pelaksanaan pemberdayaan perempuan, para agen Fatayat NU Jambi belum mempunyai pola pikir kritis dan kemampuan untuk memutuskan sehingga belum menuju transformasi pemberdayaan yang sesuai dengan nilai egalitarian.

Seiring dengan kemajuan teknologi dan imformasi di era globalisasi, semakin kompleknya persoalan-persoalan yang dihadapi oleh masyarakat khususnya pemuda dan pemudi Indonesia, tantangan yang akan dihadapi Fatayat NU semakin berat. Terdapat banyak persoalan yang terjadi ditengah masyarakat mengharuskan pengurus dan anggota Fatayat NU semakin meningkatkan perannya untuk memperjuangkan martabat perempuan dengan memperkuat pendidikan formal maupun pendidikan non formal

\section{Kekuatan Fatayat NU Pengurus Cabang (PC) Jambi}

1. Jumlah anggota Fatayat NU di berbagai daerah sangat banyak, demikian pula halnya di kota Jambi perekrutan anggota dapat dilakukan dengan mudah seperti yang sudah dilakukan oleh pengurus melalui PMII yang notabenenya kader-kader NU.

2. Pengurus Fatayat NU Cabang Kota Jambi memiliki Sumber Daya Manusia (SDM) yang representatif

3. Fatayat NU memiliki pemikiran yang moderat yang berkomitmen dalam perlindungan terhadap kelompok minoritas

4. Komunitas anggota Fatayat NU adalah perkumpulan generasi pemuda/pemudi yang masih berusia produktif

5. Fatayat NU memiliki komitmen kebangsaan yang kuat sehingga mudah bekerjasama dengan pihak-pihak terkait untuk terus membangun bangsa Indonesia 


\section{Peluang Fatayat NU Pengurus Cabang(PC) Kota Jambi}

1. Kehadiran Fatayat NU berpotensi dapat menjalin kerjasama dan mendapat dukungan yang positif dari pihak pemerintah maupun ormas yang lain

2. Sistem politik dengan memberi hak kuota 30\% bagi perempuan menempatkan Fatayat NU pada posisi strategis dan memiliki daya tawar yang tinggi

3. Sumber Daya Manusia yang dimiliki Fatayat NU sangat memedai untuk meningkatkan kualitas pendidikan

\section{Transformasi Peran Fatayat Pengurus Cabang(PC) Jambi}

Dengan bergulirnya tuntutan masyarakat di era reformasi dan tantangan yang dihadapi di era globalisasi dewasa ini, yang dapat merubah tatanan budaya dan cara pandang masyarakat dalam menyikapi kemajuan teknologi yang tidak terbendung, menuntut masyarakat disemua lini tanpa terkecuali bagi ormas-ormas yang semakin hari semakin bertambah jumlahnya, untuk melukakan perubahan, utamanya bagi organisasi di bawah payung Nahdatul Ulama(NU) yang mempunyai jumlah sangat banyak, karena komunitas NU berazas Pancasila berakidah Islam menurut faham Ahlusunah waljamaah, berdasarkan data yang diperolah berjumlah $70 \%$ dari jumlah umat Islam di dunia. 35

Perubahan peran organisasi di lingkungan Nahdatul Ulama(NU) yang menuju kepada akan adanya sebuah organisasi yang efektif dan berdaya guna bagi internal maupun eksternal Fatayat dalam menghadapi dinamika organisasi dan tuntutan kompetisi serta lingkungan yang selalu berubah, sudah saatnya Fatayat(NU) PC Jambi mengadan Political Will untuk memenuhi kebutuhan masyarakat dengan mengadakan transformasi peran dari sebagai pendamping pemerintah dalam menginplementasikan programprogram kerjanya menuju peran kemandirian yang lebih efektif.

Benar adanya bahwa, kegiatan di Internal pengurus sudah berjalan dengan bertahap seperti mengadakan seminar yang bekerjasama dengan 
Kesbangpol yang melibatkan organisasi perempuan dan mahasiswa dari berbagai Badan Eksekutif Mahasiswa(BEM), memberi tausiyah dalam pertemuan rutin satu kali sampai tiga kali seminggu dengan materi fikhi perempuan yang dinarasi oleh internal pengurus. ${ }^{36}$ Namun kegiatan yang diformat seperti ini dan tidak terprogram, seringkali menunjukkan hasil yang tidak optimal dan tidak ada folow up yang jelas dalam memajukan kualitas pendidikan masyarakat.

Dalam transformasi itu sendiri harus dilakukan perubahan peran dari fungsi sebagai pendamping berubah menjadi aktor intelektual dalam menggerakkan sumber daya manusia untuk menjadi garda paling depan dalam meningkatkan kualitas kehidupan manusia. Keniscayaan peran FatayatNU dalam mengedukasi masyarakat sangat dimungkinkan dan ditunggu oleh masyarakat Jambi yang tengah menghadapi berbagai problem kehidupan.

Persoalan yang paling utama yang dihadapi Fatayat NU Pengurus Cabang(PC) Jambi adalah bagaimana cara mengadakan transformasi di lingkungan internal organisasi tersebut?. Untuk menjawab pertanyaan tersebut adalah dengan mengidentifikasi masalah yang dihadapi oleh Fatayat $\mathrm{NU}$, dalam proses transformasi organisasi terdapat atau muncul empat tema umum yang mengkarakteristikkan proses dan bentuk transformasi itu sendiri yaitu:

1. Meredefinisikan fungsi, tugas serta peran yang harus diemban

2. Fokus kepada masyarakat, sebagai tujuan

3. Bekerja sebagai sebuah tim yang solid

4. Kepemimpinan dan shering nilai. ${ }^{37}$

\section{E. Penutup}

Fatayat NU Pengurus Cabang (CP) Jambi sudah berdiri sejak tahun 1956, telah dipimpin oleh tiga masa kepempinan hingga sekarang. Eksistensi Fatayat NU Cabang Jambi menjadi ternd tersendiri dikalangan pemudi Islam 
dan merupakan badan otonom dibawah naungan Nahdatul Ulama, ormas ini beraliran ahlusunah wal-Jamma'ah dan berazaskan Pancasila

Perekrutan anggota Fatayat NU dilakukan dengan menggunakan organisasi PMII dan perekutan melalui pengurus ranting., dengan mengisi formulir akan tetapi sampai saat ini anggota Fatayat NU belum tertata dengan baik dan belum memiliki data base yang benar karena untuk melakukan data base membutuhkan waktu yang lama.

Program Kerja Fatayat NU Pengurus Cabang Jambi, sudah berjalan meskipun belum semuanya terealisasi, namun usaha untuk melaksanakan program kerja baru terbatas dengan kemitraan bersama pemerintah daerah, belum ada program strategis dalam memajukan pendidikan masyarakat Jambi kalaupun ada usaha untuk meningkatkan kualitas pendidikan hanya terbatas pada internal organisasi.

Peluang untuk transformasi peran Fatayat NU terbuka lebar mengingat Sumber daya(SDM) yang dimiliki pengurus cukup memadai dan hubungan kerjasama Fatayat NU dengan pemerintah dan organisasi masyarat lain cukup baik, cara pandang dan pemikiran yang moderat membuat organisasi ini dapat diterima ditengah masyarakat serta didukung oleh sistem politik yang memberi peluang 30\% bagi kaum perempuan juga dapat memberi kesempatan yang luas untuk menginplementasikan program kerja.

\section{Catatan:}

1. M. Khotib Tammy, Menyoal Pergerakan Perempuan, Harian PELITA (WWW.pelita.or.id)

2. Wawancara bersama Fatimah Abbas wakil ketua Fatayat Jambi, tgl. 25Januari 2017

3 Wawancara dengan ketua Wakil Ketua Organisasi Fatayat NU Profinsi Jambi, Senin, 02-2017

4 Wawncara dengan Nurhayati Selaku Ketua Organisasi Fatayat NU Kota Jambi, 02- 2017

5 Wawancara dengan Nurhayati, selaku Ketua Organisasi Fatayat Kota Jambi, 02- 2017 
6 . Ensiklopedi Islam, Mawali-Qiblatain-Masjid, PT Ichtiar Baru Van Houve, Jilid 5 hal.166

7. Ibid

8. Ibid

9. Mukhtar dkk,Pengembangan Karir Tenaga Pendidik Teori dan Aplikasi, Magnum PustakaUtama,Yogyakarta, hal.2

10. Dokumentasi Fatayat NU Propinsi dan Kota

11 . Dewi Hanggraeni, Prilaku Organisasi, Lembaga Penerbit Fakultas Ekonomi Universitas Indonesia, hal.151

12. Wawancara dengan ketua Fatayat NU Kota, Nurhayati, tgl. 100ktober 2017

13. Wawancara dengan Pengurus, Fadlilah Husein tgl. 5 Oktober 2017

14. Wawancara dengan Nurhayati tanggal 10 Oktober

15. Wawancara dengan Nurhayati, 10 Oktober 2017

16. Wawancara dengan Nurhayati, 10 Oktober 2017

17 . Keputusan Kongres XIV... hal .30

18. Mahmud MY dan Edy Kusnadi dalam jurnal Media Akademika Volume 25,

No. 4. Oktober 2010

19 . Ibid

20. Soejono Soekanto, Sosiologi: Suatu Pengantar, Jakarta: Rajawali, 2001 dalam Mahmud MY

21. EllyPengantar Sosiologi, PT Interpratama Mandiri, 2015 Bab 15

22 Ibid . hlm. 28

23. Dalam Ahmad Tafsir, Ilmu Pendidikan Dalam Perspektif Islam, PT Remaja Rosdakarya, Bandung, 2004, hal. 24.

24 . Ibid, hal,26

25 . Ibid

26. Wawancara dengan Pengamat Pendidikan Mukhtar Latif, tanggal 60ktober 2017

27. Wawancara dengan Mukhtar Latif

28 . Republika. CO.ID, Jakarta, Saturday, 28 Januari 2017

29 . Republika. CO.ID...

30 . Wawancara dengan Mukhtar...

31. Ibid, hal. 66

32 . Wawancara dengan Nurhayati

33. Keputusan Kongres ke XIV...hal. 66

34 . Sri Roviana, Fatayat Gerakan Perempuan Nahdatul Ulama dalam Transformasi Pendidikan Politik, Jurnal Pendidikan Islam Mitra wacana Women Crisis Center Yogyakarta Volume III Nomor 2 Desember 2014

35 . Ensiklopedi Islam, Mawali-Qiblatain-Masjid, PT Ichtiar Baru Van Houve, Jilid I hal.106

36. Wawancara dengan ketua Fatayat NU Nurhayati, tanggal 21Nopember 2017

37. Musaroh, Transformasi Organisasi dan Perubahan Peran, Fungsi Sumber Daya Manusia di Era Otonomi Daerah, 


\section{DAFTAR PUSTAKA}

Ahmad Tafsir, Ilmu Pendidikan Dalam Perspektif Islam, PT Remaja Rosdakarya, Bandung, 2004

Dewi Hanggraeni, Prilaku Organisasi, Lembaga Penerbit Fakultas Ekonomi Universitas Indonesia

Ensiklopedi Islam, Mawali-Qiblatain-Masjid, PT Ichtiar Baru Van Houve, Jilid 5

Elly Pengantar Sosiologi, PT Interpratama Mandiri, 2015

Keputusan Kongres XIV Fatayat Nahdatul Ulama Tahun 2010

Mahmud MY dan Edy Kusnadi, Pembangunan Sosial Masyarakat Terasing di Era Otonomi Daerah Kasus Masyarakat Suku Anak Dalam di Muaro Jambi, jurnal Media Akademika Volume 25, No. 4. Oktober 2010

Mukhtar dkk,Pengembangan Karir Tenaga Pendidik Teori dan Aplikasi, Magnum PustakaUtama,Yogyakarta

Musaroh, Transformasi Organisasi dan Perubahan Peran, Fungsi Sumber Daya Manusia di Era Otonomi Daerah.

Republika. CO.ID, Jakarta, Saturday, 28 Januari 2017

Soejono Soekanto, Sosiologi: Suatu Pengantar, Jakarta: Rajawali, 2001

Sri Roviana, Fatayat Gerakan Perempuan Nahdatul Ulama dalam Transformasi Pendidikan Politik, Jurnal Pendidikan Islam Mitra wacana Women Crisis Center Yogyakarta Volume III Nomor 2 Desember 2014

Wawancara 